\title{
The reuse of pulp and paper mill sludge: as a soil amendment
}

\author{
Bei BeiLIU ${ }^{1}$, Xin $\mathrm{CHEN}^{1}$, Lin Wu², Miao Chen², Kai Bo Zhou ${ }^{3}$ \& Li Xu PENG ${ }^{3 *}$ \\ ${ }^{1}$ Environment and Plant Protection Institute, Chinese Academy of Tropical Agricultural Sciences, \\ Haikou, Hainan 571101, China; \\ ${ }^{2}$ Environmental Assessment and Risk Analysis Center, Chinese Academy of Tropical Agricultural \\ Sciences, Haikou, Hainan 571101, China; \\ ${ }^{3}$ Danzhou Scientific Observing and Experimental Station of Agro-Environment, Ministry of \\ Agriculture, Danzhou, Haihan 571737,China
}

KEYWORD: Paper mill; Sludge; Carbonization; Soil amendment

ABSTRACT: The pulp and paper mill sludge emissions generate a considerable amount of pollutants. Paper mill sludge is high in organic matters which could be used in agriculture as a soil amendment. In this study, a carbonization method for paper mill sludge was established and the effects of carbonized sludge on wheat growth were determined. The results showed that the optimized carbonization conditions were using $0.1 \mathrm{~mol} / \mathrm{L}$ sulfuric acid to neutralize the sludge, and then carbonized at $300^{\circ} \mathrm{C}, 0.5 \mathrm{~h}$. The carbonized products were loose and porous. The results of pot experiment showed that when the amount of added carbonized sludge were $1 \%$ to $4 \%$ of the soils, with the increase of added carbonized sludge, the growth and plant weight were increased. The greatest wheat weight was obtained at the rates of $3 \%$. The amount of $\mathrm{Pb}, \mathrm{Cd}, \mathrm{Cr}, \mathrm{Cu}, \mathrm{Zn}$ in soils did not exceed the safe controlling standards, the soil bulk density decreased, and the amount of the nutritional constituent such as N, P, and organic matter increased correspondently. So the soil qualities were improved after adding the carbonized sludge. This study indicated that carbonized paper sludge used as a soil amendment not only did not cause soil pollution but also improved the soil qualities, and then increased the plant growth when the amount of sludge applied on soil was proper.

\section{INTRODUCTION}

The industrial output of the pulp and paper industry has increased steadily over the years. According to the BRACELPA, Brazil's production in 2010 generated 540.18 thousand tons of pulp sludge and the European industry produces a total of eleven million tons of waste annually (Mymrin et al., 2015). Pulp and paper sludge is difficult to deal with because of its high water content and complex components. Most of the pulp and paper sludge were discarded in landfills or industrial dumps which became a serious environmental pollution problem.

More studies about paper mill sludge utilization have been conducted in recent years. The simplest and therefore the most common method is the use of the pulp and paper sludge as fuel (Demirbas, 2007), but the method requires a considerable expenditure of heat energy to evaporate the water contained in the sludge because the pulp and paper sludge has high moisture content. Another fairly simple method for the disposal of the pulp and paper sludge is its use as landfill covering (Zule et al., 2007; Rokainen et al., 2009). Considerable experience has been accumulated in utilizing the pulp and paper sludge as low-cost adsorbents for the treatment of wastewater laden with heavy metals (e.g. cadmium, lead), and for removal of phenols and other dangerous materials (Battaglia et al., 2003; Geng et al., 2007; Hojamberdiev et al., 2008; Hea et al., 2010; Likon et al., 2011).

Pulp and paper mill sludge are most composed by cellulosic sludge which is high in organic matters. That makes them potential candidates to be land applied (Phillips et al., 1997; Rato Nunes et al., 2008). It is necessary to study the effects of application of this waste product on soil properties and crop performance.

The aim of this study was to establish a carbonization method of paper sludge and evaluate the effects of the carbonized products on the soil chemical properties and the growth of wheat. 


\section{MATERIALS AND METHODS}

\section{Mateirals}

The paper mill sludge was sampled from Xinlin paper mill in Shanxi province, China. The main composition of sampled paper mill sludge was the waste paper pulp, lignin, cellulose, etc. The water content of the paper mill sludge was $11.3 \%$, the $\mathrm{pH}$ was 8.18 , the conductivity was $3.00 \mathrm{~ms} / \mathrm{cm}$, and the alkali content was $0.03 \%(\mathrm{NaOH})$.

\section{Optimize the Carbonization condition of PS}

The paper mill sludge was neutralized by sulfuric acid and then carbonized at high temperatures. For optimize the carbonization condition of the paper mill sludge, the acid concentration changed from 0.005 to $2 \mathrm{~mol} / \mathrm{L}$, the temperature increased from $70{ }^{\circ} \mathrm{C}$ to $300{ }^{\circ} \mathrm{C}$, and the carbonization time increased from 20 min to $4 \mathrm{~h}$ (the treatments as shown in table 2).

\section{Pot experiment}

The carbonized sludge were powdered and used as a soil amendment. A pot experiment was conducted to investigate its effects on wheat growth. Two types soil were chosen (S1, S2), and the characters of the two soils were shown in the table 1.

For the two kinds of soils, $0,2 \mathrm{~g}, 4 \mathrm{~g}, 6 \mathrm{~g}$ and $8 \mathrm{~g}$ carbonized sludge were added into $200 \mathrm{~g}$ soils of one pot (which were labeled as blank, T1, T2, T3 and T4). 9 wheat seeds were planted in one pot. One treatment had three replications. The seedling heights of different treatments were recorded during plant growth. The plant weights of different treatments were recorded after $30 \mathrm{~d}$ cultivation.

Table 1. The characters of two soils used in pot experiment.

\begin{tabular}{llllll}
\hline & $\begin{array}{l}\text { Soil } \\
\text { quality }\end{array}$ & $\begin{array}{l}\text { Water } \\
\text { content } \\
(\%)\end{array}$ & $\mathrm{pH}$ & $\begin{array}{l}\text { Organic } \\
\text { matter } \\
(\mathrm{g} / \mathrm{kg})\end{array}$ & $\mathrm{N}(\mathrm{g} / \mathrm{kg})$ \\
\hline S1 & loam & 3.10 & 7.4 & 14.416 & 2.100 \\
\hline S2 & clay & 2.57 & 8.1 & 7.226 & 1.176 \\
\hline
\end{tabular}

\section{Soil analyses}

The organic matter content, nitrogen content, phosphorous content, soil bulk density and the heavy metals $(\mathrm{Pb}, \mathrm{Cd}, \mathrm{Cr}, \mathrm{Cu}, \mathrm{Zn})$ contents of soils were determined at the end of the pot experiment. The methods of determine soil organic matter content, nitrogen content, phosphorous content and soil bulk density were according to Page (1982). Concentrations of $\mathrm{Pb}, \mathrm{Cd}, \mathrm{Cr}, \mathrm{Cu}$, and $\mathrm{Zn}$ were determined by atomic absorption spectrometry (AAS) after digestion of the samples with aqua regia according to EN 13346 (2000).

\section{RESULTS AND DISCUSSION}

\section{The optimized carbonization conditions}

The paper sludge was carbonized under different conditions. The state of carbonized products was expressed by different letters and numbers, as shown in table 2. A to E represent the state of carbonized products from hard to loose, and 1 to 5 represent the color of carbonized products from yellow to black. E and 5 were the ideal state of carbonized products.

From table 2, it can be seen that the carbonization rate increased with the increased acid concentration, and when the temperature were higher than $300^{\circ} \mathrm{C}$, the paper sludge can be carbonized. Considering the reuse of the waste acid from factory and to decrease energy consumption, $0.1 \mathrm{~mol} / \mathrm{L}$ acid concentration and $300^{\circ} \mathrm{C}$ were chosen, and the carbonization time were $0.5 \mathrm{~h}$. After the carbonization under the chosen conditions, the paper sludge was loose and porous, and the $\mathrm{pH}$ was 7.5. 
Table 2. The carbonization results of paper sludge under different conditions.

\begin{tabular}{|c|c|c|c|c|c|c|c|}
\hline \multirow{2}{*}{$\begin{array}{l}\text { Tem- } \\
\text { pera- } \\
\text { ture } \\
\left({ }^{\circ} \mathrm{C}\right)\end{array}$} & \multirow[b]{2}{*}{$\begin{array}{l}\text { Time } \\
\text { (h) }\end{array}$} & \multicolumn{6}{|c|}{ Acid concentration (mol/L) } \\
\hline & & $\begin{array}{c}0.00 \\
5\end{array}$ & 0.01 & 0.1 & 0.5 & 1 & 2 \\
\hline 70 & 4 & $\mathrm{~A}, 1$ & $\mathrm{~A}, 1$ & $\begin{array}{c}\text { A, } \\
1\end{array}$ & $\mathrm{~A}, 1$ & A, 2 & $\begin{array}{c}\mathrm{A}, \\
2\end{array}$ \\
\hline 100 & 2 & A, 2 & A, 2 & $\begin{array}{c}\text { A, } \\
2\end{array}$ & $\mathrm{~B}, 2$ & $\mathrm{~B}, 2$ & $\begin{array}{c}\text { B, } \\
2\end{array}$ \\
\hline 130 & 1 & A, 3 & A, 3 & $\begin{array}{c}\mathrm{B}, \\
3\end{array}$ & $\mathrm{~B}, 3$ & $\mathrm{~B}, 3$ & $\begin{array}{c}\mathrm{B}, \\
3\end{array}$ \\
\hline 200 & 1 & $\mathrm{~B}, 4$ & $\mathrm{~B}, 4$ & $\begin{array}{c}\mathrm{C} \\
4\end{array}$ & $\mathrm{C}, 4$ & $\mathrm{C}, 4$ & $\begin{array}{c}\mathrm{C} \\
4\end{array}$ \\
\hline 250 & 0.5 & $\mathrm{C}, 4$ & $\mathrm{C}, 4$ & $\begin{array}{c}\mathrm{D}, \\
4\end{array}$ & $\mathrm{D}, 4$ & $\begin{array}{c}\mathrm{D}, \\
4\end{array}$ & $\begin{array}{c}\mathrm{D}, \\
5\end{array}$ \\
\hline 280 & 0.5 & $\mathrm{D}, 5$ & $\mathrm{D}, 5$ & $\begin{array}{c}\mathrm{D}, \\
5\end{array}$ & $\mathrm{D}, 5$ & $\begin{array}{c}\mathrm{E}, \\
5\end{array}$ & $\begin{array}{c}\mathrm{E}, \\
5\end{array}$ \\
\hline 300 & 0.5 & E, 5 & E, 5 & $\begin{array}{c}E, \\
5\end{array}$ & $\mathrm{E}, 5$ & E,5 & $\begin{array}{c}\mathrm{E}, \\
5\end{array}$ \\
\hline$>300$ & 0.3 & E, 5 & E, 5 & $\begin{array}{c}\mathrm{E}, \\
5\end{array}$ & $\mathrm{E}, 5$ & E,5 & $\begin{array}{c}\mathrm{E}, \\
5\end{array}$ \\
\hline
\end{tabular}

\section{The effects of carbonized sludge on wheat growth}

The results of the effects of adding carbonized sludge on wheat growth are shown in figure 1. From the figure, it can be seen that for both two soils, the plant height of the treatments added carbonized sludge (T1 to T4) increased faster than the treatments without carbonized sludge (blank). With the amount of added carbonized sludge increased from 1\% to 3\% of soils (T1 to T3), the growth rates of plant height increased obviously. When the amount of added carbonized sludge increased up to $4 \%$ (T4), the increases of plant growth rates were stagnancy.

After $30 \mathrm{~d}$ pot experiment, the plant weights of different treatments were determined and the results are shown in table 3. From the table, it can be seen that the plant weights of the treatments adding carbonized sludge increased about $31.43 \%$ to $127.92 \%$ comparing the treatments without carbonized sludge. The increasing rates of T3 were the highest. The increasing rates of soil 2 were higher than that of soil 1 .

The above results indicated that adding carbonized sludge into soil at a proper amount can promote wheat growth. For low fertilizer soil, the promote effects were more obvious. 

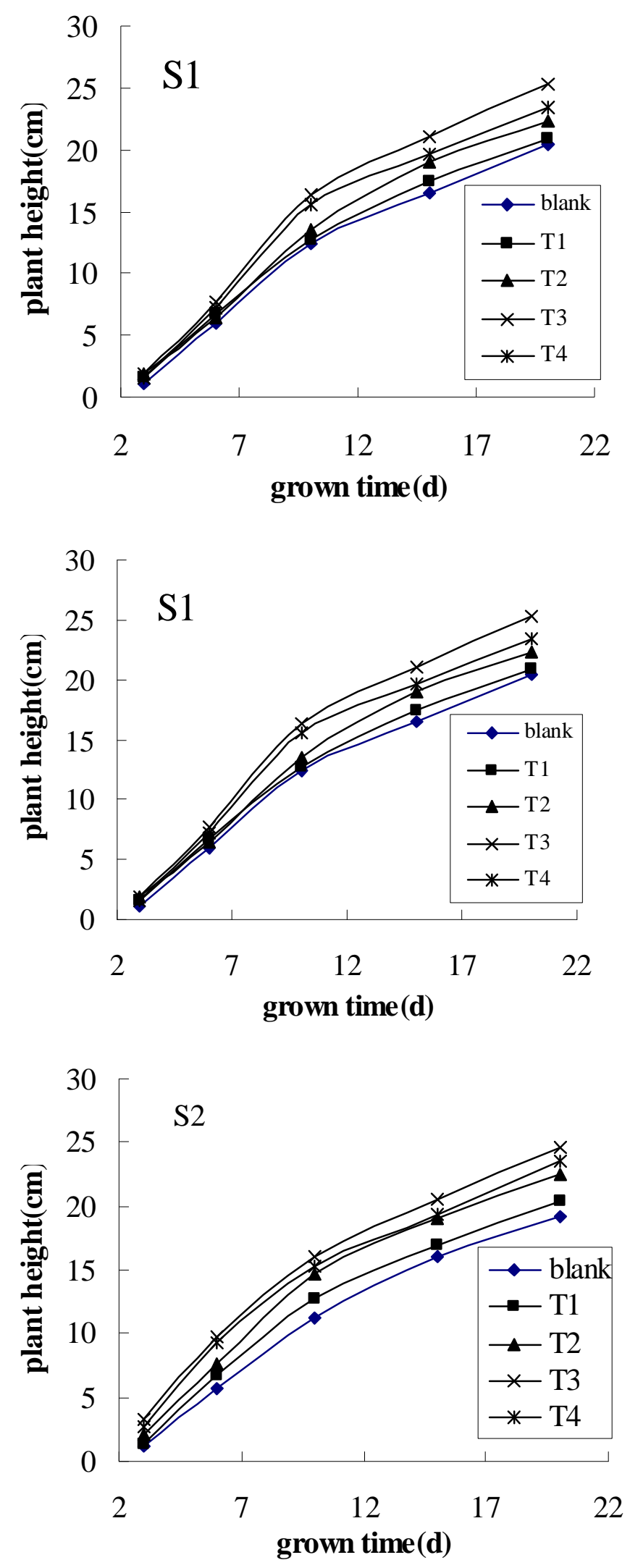

Figure 1. The effects of carbonized sludge on wheat growth. 
Table 3. The effects of adding carbonized sludge on wheat weight after 30d pot experiment.

\begin{tabular}{ccccc}
\hline & \multicolumn{2}{c}{ S1 } & \multicolumn{2}{c}{ S2 } \\
\cline { 2 - 5 } & $\begin{array}{c}\text { Plant } \\
\text { weight }(g \\
\text { dry } \\
\text { weight })\end{array}$ & $\begin{array}{c}\text { Increasing } \\
\text { rate }(\%)\end{array}$ & $\begin{array}{c}\text { Plant } \\
\text { weight/g } \\
\text { dry } \\
\text { weight }\end{array}$ & $\begin{array}{c}\text { Increasing } \\
\text { rate (\%) }\end{array}$ \\
\hline blank & 3.24 & - & 3.08 & - \\
T1 & 4.26 & 31.43 & 4.14 & 34.33 \\
T2 & 5.25 & 62.16 & 5.22 & 69.32 \\
T3 & 6.33 & 95.52 & 7.02 & 127.92 \\
T4 & 5.93 & 83.17 & 5.96 & 93.51 \\
\hline
\end{tabular}

\section{The effects of carbonized sludge on soil characters}

To explore the reason of promote effects of carbonized sludge on wheat growth, the change of soil characters, containing soil bulk density, organic matter, available $\mathrm{N}$ and $\mathrm{P}$ were determined. The results are shown in Table 4. From the table, it can be seen that after adding carbonized sludge, the soil bulk densities were decreased, the organic matter, available $\mathrm{N}$ and $\mathrm{P}$ were increased. Those changes of soil characters were all benefit for wheat growth. It can be conclude that carbonized sludge improved the soil qualities and then promote plant growth.

Table 4. The effects of adding carbonization sludge on soil characters.

\begin{tabular}{cccccc}
\hline & & $\begin{array}{l}\text { Soil } \\
\text { bulk } \\
\text { density } \\
\left(\mathrm{g} / \mathrm{cm}^{3}\right)\end{array}$ & $\begin{array}{l}\text { Organic } \\
\text { matter } \\
(\mathrm{g} / \mathrm{kg}\end{array}$ & $\begin{array}{l}\text { Availa- } \\
\text { ble N } \\
(\mathrm{mg} / \mathrm{kg})\end{array}$ & $\begin{array}{l}\text { Availa- } \\
\text { ble P } \\
(\mathrm{mg} / \mathrm{kg})\end{array}$ \\
\hline $\mathrm{S}$ & blank & 1.29 & 14.416 & 145.40 & 21.97 \\
1 & $\mathrm{~T} 1$ & 1.27 & 14.58 & 146.16 & 25.87 \\
& $\mathrm{~T} 2$ & 1.22 & 16.52 & 149.71 & 28.49 \\
& $\mathrm{~T} 3$ & 1.15 & 16.32 & 165.96 & 30.24 \\
& $\mathrm{~T} 4$ & 1.09 & 16.78 & 161.39 & 30.17 \\
\hline $\mathrm{S}$ & blank & 1.46 & 7.226 & 102.71 & 19.27 \\
2 & $\mathrm{~T} 1$ & 1.38 & 9.38 & 122.45 & 21.45 \\
& $\mathrm{~T} 2$ & 1.23 & 10.63 & 132.74 & 23.78 \\
& $\mathrm{~T} 3$ & 1.17 & 10.85 & 144.69 & 26.41 \\
\cline { 2 - 6 } & $\mathrm{T} 4$ & 1.10 & 11.40 & 142.39 & 24.04 \\
\hline
\end{tabular}

\section{The heavy metals risk of carbonized sludge use on soil}

The benefits of paper sludge as an agricultural soil amendment are obvious, which allows maintaining or restoring the quality of soils, reducing the need for inorganic fertilizers. However, a wide variety of undesired traits can have adverse effects on the environment as a consequence of this practice. So it is important to gather knowledge on the risk of the use of paper sludge as agricultural soil amendments. 
Table 5. The effects of adding carbonized sludge on contents of heavy metals in soils.

\begin{tabular}{ccccccc}
\hline & & $\mathrm{Cu}$ & $\mathrm{Cr}$ & $\mathrm{Cd}$ & $\mathrm{Pb}$ & $\mathrm{Zn}$ \\
\hline S1 & blank & 1.13 & 0.11 & - & 4.90 & 2.85 \\
& T1 & 1.85 & 0.35 & - & 4.85 & 2.95 \\
& T2 & 1.86 & 0.35 & 0.05 & 5.10 & 3.15 \\
& T3 & 1.90 & 0.40 & 0.05 & 5.20 & 3.50 \\
& T4 & 2.05 & 0.45 & 0.05 & 5.30 & 3.75 \\
\hline S2 & blank & 1.25 & 0.10 & - & 4.25 & 2.64 \\
& T1 & 1.95 & 0.33 & - & 4.34 & 2.75 \\
& T2 & 1.96 & 0.34 & 0.04 & 4.57 & 2.82 \\
& T3 & 2.10 & 0.38 & 0.05 & 4.89 & 3.02 \\
& T4 & 2.15 & 0.41 & 0.05 & 5.00 & 3.15 \\
\hline Soil quality & $\leq 100$ & $\leq 300$ & $\leq 0.45$ & $\leq 80$ & $\leq 250$ \\
standard * & & & & & \\
\hline
\end{tabular}

* Chinese environmental quality standard for soils (GB15618-2008), level 2, $\mathrm{pH}>6.5$.

The most attentions on the risks of sludge on land use are heavy metals. In this study, we determined the heavy metals contents of soils adding carbonized sludge. The results are shown in Table 5. From the results, the amounts of $\mathrm{Pb}, \mathrm{Cd}, \mathrm{Cr}, \mathrm{Cu}, \mathrm{Zn}$ in soils with carbonized sludge were increased little than the blank soils, which did not exceed the safe controlling standards. It indicated that the use of carbonized sludge on soil did not have heavy metal risks.

\section{CONCLUSIONS}

From the study, we find a novel reuse method of paper mill sludge. At first, the paper sludge need to be carbonized under the optimized conditions: using $0.1 \mathrm{~mol} / \mathrm{L}$ sulfuric acid to neutralize the sludge, and then carbonized at $300^{\circ} \mathrm{C}, 0.5 \mathrm{~h}$. Then the carbonized products can be used as soil amendment. The results of pot experiment indicated that adding carbonized sludge into soil at a proper amount can promote wheat growth. For low fertilizer soil, the promote effects were more obvious. The soil bulk density decreased, and the amounts of the nutritional constituent such as N, P, and organic matter increased correspondently, which is the main reason of promote effects of carbonized sludge on wheat growth. The amount of $\mathrm{Pb}, \mathrm{Cd}, \mathrm{Cr}, \mathrm{Cu}, \mathrm{Zn}$ in soils did not exceed the safe controlling standards. In summary, carbonized paper sludge used on soil as a soil amendment not only did not cause soil pollution but also improved the soil qualities, and then increased the plant growth when the amount of sludge applied on soil was proper.

\section{ACKNOWLEDGEMENTS}

This work was supported by the Fundamental Research Funds for Environment and Plant Protection Institute, CATAS (No. 2012hzs1J008, 2015hzs1J004) and the National Natural Science Foundation of China (No. 41301555).

\section{REFERENCES}

[1] Mymrin, V., Klitzke. W., Alekseev. K., et al. 2015. Red clay application in the utilization of paper production sludge and scrap glass to fabricate ceramic materials. Applied Clay Science 107: 2835.

[2] Demirbas, A., 2007. Progress and recent trends in biofuels. Prog. Energy Combust. Sci. 33(1): $1-18$. 
[3] Zule, J., Černec, F. \& Likon, M., 2007. Chemical properties and biodegradability of waste papermill sludge to be used for landfill covering. Waste Manag. Res. 6 (25), 538-546.

[4] Rokainen, N., Kujala, K. \& Saarela, J., 2009. Use of industrial by-products in landfill cover. Proceedings Sardinia, Twelfth International Waste and Landfill Symposium, S. Margarita di Pula, Cagliari, Italy.

[5] Battaglia, A., Calace, N., Nardi, E.M., et al., 2003. Paper mill sludge-soil mixture: kinetic and thermodynamic tests of cadmium and lead sorption capability. Microchem. J. 75, 97-102.

[6] Geng, X., Deng, J. \& Zhang, S.Y., 2007. Paper mill sludge as a component of wood adhesive formulation. Holzforschung 61 (6): 688-692.

[7] Hea, X., Yaoa, L., Lianga, Z., et al., 2010. Paper sludge as a feasible soil amendment for the immobilization of $\mathrm{Pb}^{2+}$. J. Environ. Sci. 22: 413-420.

[8] Hojamberdiev, M., Kameshima, Y., Nakajima, A., et al., 2008. Preparation and sorption properties of materials from paper sludge. J. Hazard. Mater. 151: 710-719.

[9] Likon, M., Černec, F., Svegl, F., et al., 2011. Paper mill industrial waste as a sustainable source for high efficiency absorbent production. Waste Manag. 6 (31): 1350-1356.

[10] Phillips, V. R., Kirkpatrick, N., Scotford, I.M., et al., 1997. The use of paper-mill sludges on agricultural land. Bioresour. Technol. 60: 73-80.

[11] Rato Nunes, J., Cabral, F. \& López-Piňero, A., 2008. Short-term effects on soil properties and wheat production from secondary paper sludge application on two Mediterranean agricultural soils. Bioresour. Technol. 99: 4935-4942.

[12] Page, A.L. 1982. Methods of soil analysis, second edition. ASA Press, New York.

[13] EN 13346, 2000. Characterization of sludges-Determination of trace elements and phosphorusAqua regia extraction methods. European Standards. 